Jurnal Akademia, Volume 1, Nomor 1, Juli-September, 2014

\title{
Interactive Patterns of Language Learning Strategy
}

\author{
Riana Agustin Tindjabate \\ Universitas Kristen Tentena
}

\begin{abstract}
The purpose of this study was to find out secondary school students' frequent choices of the IPs-LLS. The study was conducted as Sekolah Menengah Umum Gereja Kristen Sulawesi Tengah 2 Tentena (SMU GKST 2 Tentena), Central Sulawesi, with 75 students as the respondents. The primary data of this study was the students' respondents on language learning strategy. In this study, all the respondents were asked to fill in the questionnaire containing of 50 questions concerning language learning strategy (LSS). Overall, the analysis results showed that the LLS were sometimes used by the students. However, there were two interactive patterns of the LSS that were reported frequently used, these were "I ask for correction when I talk" and "I ask for help from English speakers". This study did not explore deeply the respondents' meaning about which English speakers were. But, it revealed respondents' needs towards other people when they learned English. To conclude, the findings of the study support the implementation of social constructivist theory in EFL classroom. It implies that English teachers should develop their strategy of teaching becoming more constructive and interactive.
\end{abstract}

\begin{abstract}
Abstrak
Tujuan penelitian ini adalah untuk menemukan pilihan strategi belajar bahasa Inggris yang sering digunakan oleh siswa menengah umum. Penelitian ini dilaksanakan di Sekolah Menengah Umum Gereja Kristen Sulawesi Tengah 2 Tentena (SMU GKST 2 Tentena) dengan jumlah responden 75 siswa. Data utama dalam penelitian ini adalah respon siswa terhadap strategi belajar bahasa yang sering mereka gunakan. Semua responden diminta untuk menjawab semua pernyataan dalam angket yang terdiri atas 50 pertanyian tentang strategi belajar bahasa asing. Analisa data secara keseluruhan menunjukkan bahwa strategi belajar bahasa asing tidak terlalu sering digunakan oleh siswa. Meskipun demikian, penelitian ini juga menemukan 2 pola interaktif dari strategi belajar yang hampir sering digunakan oleh siswa. Dua pola interaktif tersebut adalah "I ask for correction when I talk" dan "I ask for help from English speakers". Penelitian ini tidak menggali lebih dalam tentang siapakah yang dimaksud oleh responden tentang English Speakers tetapi hal ini menunjukkan bahwa para responden membutuhkan orang lain ketika belajar bahasa Inggris. Peneliti menyimpulkan bahwa penemuan dalam penelitian ini mendukung implementasi teori para pakar konstruktivisme sosial dalam kelas pembelajara bahasa Inggris sebagai bahasa asing dan implikasi dari penelitian ini adalah guru harus mengembangkan strategi mengajar yang bersifat konstruktif dan interaktif
\end{abstract}




\section{A. INTRODUCTION}

Analytical description on the present situation of interactive of language learning strategy (IPs-LSS) use is rarely conducted in Indonesia. Mostly, educators approach their studies on language learning strategy by investigating learners' belief and its relation to the learners' motivation in learning English (Rahman, 2005: 29-55), studying learners' belief and its relation to affective aspects (Ellis, 2008: 7-24), correlating learners' personality traits with learners' performance in writing tasks (Soleimani, 2010: 93-106), implementing various learning strategies to less able students (Noom-Uram 2008: 173-192), and investigating relationship between authentic English Foreign Language (EFL) learning environment and students' ability in recognizing their LLS that suit their needs (Vivian Wu, 2008:211-226). The most close of LLS research to the current study is the examination of LLS used by higher and lower proficiency EFL students at National Chin-Yi University of Technology in Taiwan which was conducted by $\mathrm{Wu}$ (2008:75-95) and Griffiths' study on patterns of LLS use at a private English language school for international students in Auckland (2003:367383). The current study aims at describing the present situation of IPs-LLS use among secondary schools students in order to make the students aware of the importance of IPs-LLS in English learning.

IPs-LLS use is very important for the development of students' communicative competence in English. Recently, English language teaching, in many countries including in Indonesia, is emphasized on communicative language teaching (CLT) approach (McKay, 2002:106 Albert and Kormos, 2004:284). This movement has affected students' choices of learning strategy. The students tend to use interactive learning strategies in learning English even though English is learnt as EFL subject in Indonesia. It means the students are likely to learn English by using more social strategy because they want to use English for communication purpose.

Concerning interactive language learning strategy used by students who learn English, Griffiths (2003:378), in her study, suggests six interactive patterns of language learning strategy (LLS) which are categorized as "plus" strategy. These are I start conversation in English (IP-1), I look for people I can talk to in English (IP-2), I ask for correction when I talk (IP-3), I practice English with other students (IP-4), I ask for correction when I talk (IP-5), and I try to learn the culture of English speakers (IP-6). The six strategies are related to students' interaction with other people in English and with the culture as the effect of CLT movement in English language teaching (Griffiths, 2003: 378). Thus, CLT movement has brought social interaction to an important position that, as a core of communication, it plays significant role in language learning. Referring to Brown (2001:165), interaction is the heart of communication where everything about communication happens in interaction, moreover, Oxford suggests that involvement other people in the process of learning a language is very important because language is communication (1990:144). Bandura agrees with the concept regarding the role of interaction in learning process by saying that people cannot achieve their accomplishment on their own ability, they need other's help (2001:13). The role of social interaction in language learning is actually an important element of constructing knowledge and understanding of the target language.

The current study does not examine the implementation of IPS-LLS in English classroom but it is conducted to understand in depth two research focuses. These are the most IPs-LLS used by secondary school students and factors affecting the students' choices of the IPs-LLS. By answering the research focuses, two expectations in conducting this study are expected to be achieved. Firstly, the study will give practical benefit about IPs-LLS use to EFL teachers and students of secondary school. Secondly, the study is expected to give new perception about the use of IPs-LLS among secondary school students in Indonesian context.

\section{B. RESEARCH METHODS}

The study was conducted at SMU GKST 2 Tentena, Poso District, Central Sulawesi in two months started in February 
2014 till March 2014. The study was designed into two phases, questionnaire distribution and semi structured interview.

The target population was 375 students of academic year 2013/2014. The samples were 75 students taken from $20 \%$ of the total population. The samples were selected through random sampling (lottery system) adopted from Gay (1981).

The researcher played role as a full observer in this study and was helped by the teacher of English at SMU GKST 2 Tentena. The researcher collected the IPs-LLS data by distributing 50-item of the SILL questionnaire. Data about factors affecting the students' choices of IPs-LLS were obtained through list of question in the form of semi structured interview. The IPs-LLS data was examined by using the SILL mean reported frequency of use (Griffiths, 2003).

The IPs-LLS and interview data were analyzed by using Miles and Huberman's theory of analyzing qualitative data (Emzir, 2010:129135). Three steps were conducted to analyze the data. First, data reduction was held by categorizing the data into two main parts; the IPs-LLS mostly used by the students and factors that tightly related to the students' choice of IPs-LLS. Second, data display in the form of SILL graph was used to show the frequency of use and single tabulation distribution was used to show factors affecting the students' choice. Third, the researcher drew and verified the conclusion.

\section{RESEARCH RESULTS}

There are three patterns categorized as important IPs-LLS by the students and the rest are categorized as not very important patterns. IP-1 is reported sometimes used (mean 2.7), IP2 is reported not generally used (mean 2.4), IP-3 is reported usually used (mean 3.7), IP-4 is reported sometimes used (mean 3.4), IP-5 is reported usually used (mean 3.6), and IP-6 is reported not generally used (mean 2.3). Overall average for the six IPs-LLS is reported at mean 3. However, it is analytical described that IP-3 and IP-5 have mean reported frequency of use above 3.5 and reportedly used highly frequently by the students.
There are four factors affecting students' choices of interactive patterns of LLS in the classroom; students' belief about language learning, the learning setting, the language being learnt, and the type of learning tasks. In the current study, students' responses on the four factors are related to the six interactive patterns of LLS that have been formerly discussed. The study found that $100 \%$ of the students' belief about language learning on IP-3 can improve their English. There are 97.4\% of the students said that EFL setting in the classroom affect them to choose IP-3 while there are $96 \%$ of the students said that learning English as EFL subject has affected them to choose IP-5 even though this strategy is categorized as not very important. The type of learning tasks such as dialogue, conversation, and speaking have affected $96 \%$ of the students to choose IP-5. However, there is one interactive pattern which is not strongly affected by the four factors. This is IP-6 or "I try to learn about the culture of English speakers, it is the most IP avoided by the students in learning EFL subjects.

\section{DISCUSSION}

There are two strategies that reportedly used highly frequently, IP-3 "I ask for correction when I talk" and IP-5 "I ask for help from English speakers". The two interactive patterns that reportedly used highly frequently are related to asking of other people's help for correction. The students say that asking for correction can help them to improve their English such as correction on pronunciation and grammatical aspects. It means the students' choices of the interactive patterns is strongly affected by their beliefs about interaction to others and the learning setting where the students are usually asked by the teacher to complete tasks in EFL classroom which they need others' help to correct their tasks. Interestingly, the two strategies only relate to asking others' help not starting conversation, looking for people for talking, practicing English, or learning culture. The students' choices are affected by the four factors as mentioned in the previous part. $100 \%$ of the students rely on IP-3 in learning English which means all of the students believe IP-3 playing 
important role in and outside the classroom. Unfortunately, most of the students do not use English when they ask for correction, they use Bahasa.

The other strategies are categorized as medium and low level of use. IP-4 "practicing English with other students" (mean 3.4), IP-1 "starting conversation in English" (mean 2.7), IP-2 "looking for people I can talk to in English (mean 2.4), and IP-6 "trying to learn the culture of English speakers (mean 2.3). The overall average use of these 6 interactive patterns of LLS is 3 which mean the patterns are sometimes used. Interestingly, none of the six IPs-LLS is reported having mean 1.5 or below. It means all the patterns have been ever used by the students but the teacher needs to promote more the use of the patterns by teaching the strategies in the classroom especially IP-6 which is analytically described as not very important strategy and not frequently used by the students in learning English.

IP-6 is reported as the lowest use among the students. Only $6.7 \%$ of the students try to learn the culture of English speakers while $32 \%$ never or almost never use the patterns while in line with EFL learning setting there are $45.3 \%$ of the students who cite that the learning setting does not affect them to choose IP-6 in learning English. This is in contradiction with social constructivist theory which suggests culture and context as important parts in learning as knowledge and understanding cannot be constructed without culture and context. This means students should learn the culture of English speakers because learning English cannot be separated from learning the culture as language itself is a part of culture. The reason for not using frequently this pattern is because the students do not see the strong relationship between learning culture and learning language. In line with the students' opinion, it is possible new information received by the learner contradicting with the learner's pre existing knowledge so the teacher have to select, adapt and determine teaching materials relating to the culture based on the learner's pre existing knowledge (Pritchard and Woollard, 2010:12-13). Teacher should help the students to be aware of the importance of learning the target culture of English speakers with their
English learning because culture is an integral part of language and thought. I believe in this sense the students should understand that language cannot be separated from culture because language is shaped by human culture. Therefore, promoting learning the culture of English speakers in the classroom is significant to improve students' ability in using English whatever purpose. Teacher of English must be actually aware of this concept if they want to lead students to be independent learners in and outside the classroom. However, teacher should carefully select which target culture that best suits students' needs in learning English and continuously give deep understanding to students why they should learn the culture of English speakers. In terms of students' priority scale on the IPs-LLS, the current study analytical describes IP-1, IP-2, and IP-3 as important interactive patterns of LLS among the students, however, only IP-3 is reportedly used highly frequently by the students while IP-5 which is categorized as not very important pattern is also reportedly used highly frequently. The results show several contradictions between the students' scale priority and the frequency of IPs of LLS use. Even though particular patterns are categorized as important strategy in learning English but is does not mean the students will use the patterns highly frequently. The students' perceptions and the mean frequency of the IPs-LLS use have revealed some contradictions about IPs-LLS in the real life and in the students' mind. In relation to the both aspects, the current study found that the students use IPs-LLS not only for constructing knowledge and understanding but also for social function where IPs-LLS can help them to be seen as an intelligent and professional person, they won't be left away behind among the other peers, and they can find more friends.

\section{E. CONCLUSION AND SUGGESTION}

The most interactive patterns of language learning strategy used by secondary school students are IP-3 and IP-5. The two interactive patterns show that the students are active thinkers who actively interact in English by asking correction ad help from others. Most of the students believe that the interactive patterns can improve their ability of English and 
this is in line with social constructivist theory. However, social constructivist theory not only point out the important role of social interaction in the development of students' knowledge, but also has social function in which the students can increase their social status among other peers and within their community. The researcher suggests other researchers to conduct a study on the implementation of learning the culture of English and its effect to the students' proficiency English skills.

\section{REFERENCES}

Albert, Agnes and Kormos, Judit. (2004). Creativity and Narrative Task Performance: An Exploratory Study. Language Learning. Sent by Nasmilah Imran (imla63@yahoo.com) to Riana Agustin Tindjabate (ra_tindjabate@yahoo.co.id)

Bandura, Albert. (2001). Social Cognitive Theory: An Agentic Perspective. Annual Reviews (Online), retrieved on 17 March 2012. Available from: http://www.AnnualReviews.org/

Brown, H. Douglas. (2001). Teaching by Principles. An Interactive Approach to Language Pedagogy. Second Edition. New York : Addison Wesley Longman Inc.

Ellis, Rod (2008). Learner Beliefs and Language Learning. Conference Proceedings of the Asian EFL Journal (Online) Vol. 10, No. 4, downloaded on 3 October 2011. Available from: http://www.asian-efljournal.com/

Griffiths, Carol. (2003). Patterns of Language Learning Strategy Use. System Journal 9Online), downloaded on4 May 2011. Available from: http://www.elsevier.com/locate/system

Gay, L.R (1981). Educational Research. Columbus, Ohio: Charles.E.Merrill Publishing Co.

McKay, Sandra Lee (2002). Teaching English as an International Language. Oxford:OUP

Noom-Ura, Sripathum. (2008). Teaching ListeningSpeaking Skills to Thai Students with Low English Proficiency. Conference Proceedings of Asian EFL Journal (Online) Vol.10, No.4, downloaded on 3 October 2011. Available from: http://www.asian-efljournal.com/
Oxford, Rebecca L. (1990) Language Learning Strategies: What Every Teacher Should Know. New York: Newbury House Publishers.

Pritchard, Alan and Woollard, John. (2010). Psychology for the Classroom: Constructivism and Social Learning. Taylor and Francis e-Library (Online). Available from: http://www.eBookstore.tandf.co.uk/

Rahman, Sayeedur. (2005). Asian EFL Journal. Orientations and Motivations in English Language Learning: A Study of Bangladeshi Students at Undergraduate Level. Asian EFL Journal (Online) Vol.7, No.1, downloaded on 3 October 2011. Available from: http://www. Asian-efl-journal.com/

Soleimani, Mohammad Mehdi and Daryabari, Mahmoud Reza. (2010). The Impact of Personality Traits on the Writing Performance of Iranian EFL learners. Asian ESP Journal (Online) Vol.6, No.2, downloeaded on 3 October 2011. Availabe from: http://www.asian-esp-journal.com/

Vivian Wu, Wen-Chi and Natalie Wu, Pin-Hsiang (2008). Asian EFL Journal. Creating an Aunthentic EFL Learning Environment to Enhance Students Motivation to Study English. Conference Proceedings of Asian EFL Journal (Online) Vol.10, No 4, downloaded on 3 October 2011. Available from: http://www. asia-efl-journal.com/

Wu, Ya-Ling. (2008). Language Learning Strategies Used by Students at Different Proficiency Levels. Conference Proceedings of Asian EFL Journal (Online) Vol.10, No.4, downloaded on 3 October 2011. Available from: http://www.asian-efljournal.com/ 